\title{
Vulvar Cancer pT1a TNM Finding v8
}

National Cancer Institute

\section{Source}

National Cancer Institute. Vulvar Cancer pT 1a TNM Finding v8. NCI Thesaurus. Code C139602.

Vulvar cancer with lesion measuring $2 \mathrm{~cm}$ or less, confined to the vulva and/or perineum, and with stromal invasion of $1.0 \mathrm{~mm}$ or less. (from AJCC 8th Ed.) 